\title{
KEKALAHAN KEBERAGAMAN DI RUANG PUBLIK ATAS FATWA SESAT MUI: PENDEKATAN SEMANTIK TERHADAP TERM DALAL DALAM ALQURAN
}

\author{
Moh. Yardho \\ Universitas Islam Negeri Sunan Ampel Surabaya \\ yardlo@gmail.com
}

\begin{abstract}
Indonesia constitutionally guarantees the freedom of religion to the whole of citizens. But the fact stated that these rules have clashed oftentimes with the acts of vandalism against certain religious groups, especially within the scope of religion or minority sects. The violent acts occur partly because there is one group that has a basic reference about what and how religion should be carried out in the public sphere. In this case, the MUI formulates 10 criteria for heretical flow, which on one hand can be a formulation of "true" religious boundaries, but on the other hand aims to preserve the exclusive ideas. Against this phenomenon, this study attempts to reveal the Qur'anic views on the issue of religious freedom, through a semantic approach to terms dalal. Furthermore, the Qur'anic discourse will be synthesized with the discourse of the nation state and social capital. The two syntheses, in turn, present the conclusion that religious freedom finds its Qur'anic reference and reveals its relevant in the Indonesian public sphere.
\end{abstract}

Keywords: MUI, dalal, religious freedom, semantics.

Abstrak: Secara konsitusional, Indonesia menjamin hak kebebasan beragama seluruh warga negaranya. Namun pada dataran realitas, aturan tersebut berbenturan dengan fakta bahwa aksi vandalisme terhadap kelompok keagamaan tertentu, terutama dalam lingkup agama atau aliran minoritas, masih kerap menjadi fenomena. Perilaku kekerasan terjadi antara lain karena terdapat satu kelompok yang memiliki acuan dasar tentang apa dan bagaimana seharusnya beragama dijalankan dalam ruang publik. Dengan kata lain, narasinarasi eksklusif masih menjadi acuan kelompok tertentu. Dalam hal ini, MUI merumuskan 10 kriteria aliran sesat, yang pada satu sisi dapat menjadi rumusan tentang batasan beragama secara "benar", namun pada sisi lain menyimpan ide eksklusif. Berlatar fenomena tersebut, penelitian ini bertujuan untuk mengungkap pandangan Alquran tentang isu kebebasan beragama, melalui pendekatan semantik terhadap term dalall. Lebih lanjut, wacana Alquran tersebut akan disintesakan dengan diskursus negara bangsa dan social capital. Pada 
gilirannya kedua sintesa tersebut menghadirkan simpulan bahwa kebebasan beragama menemukan referensial Alquran dan relevan dalam ruang publik Indonesia.

Kata Kunci: MUI, ḍalal, kebebasan beragama, semantik.

\section{Pendahuluan}

Dalam pandangan Bruce B. Lawrence, "Islam adalah banyak hal... tidak ada lokasi tunggal ataupun budaya seragam yang identik dengan Islam. Dengan demikian, tidak ada Islam yang monolitik." Pandangan ini menemukan realisasinya di dalam negara multikultural, seperti Indonesia. Secara faktual, Indonesia menjadi tempat bertemunya berbagai komunitas dengan latar belakang yang berbeda, termasuk agama yang beragam. Tidak berhenti di situ, dalam satu agama juga mengalami karakteristik satu sama lain yang berbeda.

Realitas tersebut di satu sisi dapat menyumbang khazanah peradaban yang khas. Namun, di sisi yang lain, berpotensi memicu konflik destruktif antar komunitas ketika keragaman tersebut tidak dikelola dengan baik, terlebih ketika menyangkut keragaman agama. Menyadari hal itu, untuk menjaga kondusifitas ruang publik, para founding father bangsa Indonesia memandatkan adanya jaminan bebas berkeyakinan dan beribadah sebagaimana termaktub dalam pasal $28 \mathrm{e}$ dan pasal 29 UUD $1945 .^{2}$

Dengan demikian, secara prinsip-konstitusional, kebebasan mengimani agama atau kepercayaan tertentu berikut ekspresi beribadahnya menjadi hak asasi semua rakyat dan mendapat jaminan perlindungan dari negara. Namun, prinsip tersebut terasa hanya berupa pseudo, karena masih kerap absen dalam realitas publik, melihat maraknya berbagai konflik yang terjadi atas nama golongan.

Dalam laporan tahunan The Wahid Institute pada tahun 2015, terdapat 84 konflik berbasis keyakinan, berupa perusakan tempat ibadah, pengusiran warga dari desa, penahanan pengurus aliran kepercayaan oleh polisi. ${ }^{3}$ Sedang menurut laporan tahunan Setara Institute, hingga pertengahan tahun 2018, terdapat 109 peristiwa

1 Bruce B. Lawrence, Islam Tidak Tungggal: Melepaskan Islam Dari Kekerasan, terj. Harimukti Bagoes Oka (Jakarta: Serambi Ilmu Semesta, 2004), 11.

${ }^{2}$ Nino (ed.), UUD 1945 \& Kabinet Kerja 2014-2019 (Jakarta: Salaris, t.th.), 36-40.

3 The Wahid Institute, Laporan Sementara Dinamika Kebebasan Beragama dan Berkeyakinan (KBB) di Indonesia Tabun 2015. Versi PDF. 
pelanggaran kebebasan beragama dan berkeyakinan. ${ }^{4}$ Fakta tersebut menunjukkan kelalaian negara sebagai pengawal sentral berjalannya undang-undang kebebasan beragama. Ironisnya, agama mayoritas turut memperkeruh konflik dengan menggiring diskursus publik. Dalam konteks ini, fatwa sesat Mejalis Ulama Indoensia (MUI) dapat menjadi contoh. ${ }^{5}$

Fatwa MUI adalah bukti telak bagaimana agama mayoritas Indonesia (baca: Islam) membangun benteng eksklusivisme dalam beragama, yang kerap berujung pada aksi premanisme terhadap kelompok keagamaan minoritas. Karenanya, Nurcholis Madjid mengatakan, tidak ada masa depan dalam keberagamaan yang dikembangkan secara eksklusif. Cepat atau lambat eksklusivisme akan membawa pada kehancuran. ${ }^{6}$ Di sisi lain, banyak tokoh yang pro atas fatwa yang dikeluarkan MUI. Haidar Bagir misalnya, berpendapat bahwa fatwa MUI dapat menjadi batasan pemahaman yang sesuai dengan Islam dan menjaga ketertiban sosial. ${ }^{7}$ Terlepas dari berbagai pendapat di atas, pertanyaannya, bagaimana Alquran mengatur kebebasan beragama manusia, termasuk solusi apa yang ditawarkan? Sebab carut-marut kebebasan beragama di tanah air kerap terjadi dari tahun ke tahun.

\section{Sesat dalam Produksi Fatwa MUI}

Tahun 1975, Presiden Soeharto mendorong pendirian lembaga Majelis Ulama Indonesia (selanjutnya disebut MUI). Atas tindakannya itu, tidak sedikit analis studi keindonesiaan berpendapat bahwa

\footnotetext{
${ }^{4}$ Lihat laporan Setara Institute, Kondisi Kebebasan Bergama/Berkeyakinan dan Minoritas di Indonesia tabun 2018. Versi PDF.

${ }^{5}$ Adapun kriteria sesat versi MUI adalah: (1) mengingkari salah satu rukun iman dan Islam, (2) meyakini atau mengikuti akidah yang tidak sesuai dengan dalil syar'i (alQur'an dan al-Sunnah), (3) mayakini turunnya wahyu setelah al-Qur'an, (4) mengingkari otentisitas dan atau kebenaran isi al-Qur'an, (5) melakukan penafsiran al-Qur'an yang tidak berdasarkan kaidah tafsir, (6) mengingkari kedudukan hadis nabi sebagai sumber ajaran Islam, (7) menghina, melecehkan, dan atau merendahkan para nabi dan rasul, (8) mengingkari Nabi Muhammad sebagai Nabi dan Rasul terakhir, (9) merubah, menambah, dan atau mengurangi pokok ibadah yang telah ditetapkan syari'ah dan (10) mengafirkan sesama Muslim tanpa dalil syar'i. Lihat Al Makin, Nabi-nabi Nusantara (Yogyakarta: Suka Press, 2017), 190.

${ }^{6}$ Nurcholis Madjid, Cendekiawan dan Religiusitas Masyarakat (Jakarta: Paramadina, 1999), 60 .

${ }^{7}$ Haidar Bagir, Islam Tuban Islam Manusia: Agama dan Spiritualisme di Zaman Kacau (Bandung: Mizan, 2014), 139-140.
} 
Soeharto, bertendensi menjadikan MUI sebagai kepanjangan tangan pemerintah. Kemunculan lembaga ini memang dapat dipandang sebagai refleksi lebih lanjut dari kesadaran akan pentingnya pelembagaan peran profetik ulama. Namun, menilik tabiat Orde Baru dan konstelasi politik saat kemunculannya, MUI didorong berdiri dalam kerangka kepentingan untuk menjadikannya sebagai "state aparatus" yang mengontrol dinamika keberagaman masyarakat agar tidak mengganggu kekuasaan rezim Orde Baru sekaligus memberinya legitimasi keagamaan. ${ }^{8}$

Anggapan demikian tentu saja dibantah kalangan MUI. Dalam situs resminya dijelaskan, bahwa berdirinya MUI adalah hasil dari musyawarah ulama dan zuama (pemimpin) yang datang dari berbagai penjuru tanah air.' Tujuan berdirinya antara lain untuk: (1) memberi bimbingan dan tuntunan kepada umat Islam Indonesia dalam mewujudkan kehidupan beragama dan bermasyarakat yang diridhai Allah, (2) menjadi penghubung antara ulama dan umara (pemerintah) guna mensukseskan pembangunan nasional. ${ }^{10}$

Penjabaran dan penyebutan konteks latar belakang tersebut memang versi resmi MUI, sehingga wajar jika sangat normatif. Versi resmi tersebut tentu berlawanan dengan fakta sesungguhnya yang kental kepentingan. Menurut Ali Mufradi, sebagaimana dikutip oleh Fawaizul Umam, hal tersebut kian jelas ketika Soeharto turut mendesakkan perlunya suatu lembaga atau wadah keulamaan yang dapat membantu pemerintah dalam menciptakan harmoni, keserasian dan toleransi. Desakan tersebut disampaikan setidaknya dalam dua kesempatan. Awal mula disampaikan saat memberi sambutan penutup acara lokakarya mubalig se-Indonesia di Jakarta, 26-29 November 1974. Kemudian diulang lagi ketika dirinya menerima Pengurus Dewan Masjid Indonesia di Jakarta, 24 Mei $1974 .{ }^{11}$

Menteri Dalam Negeri (Mendagri) dan Menteri Agama berperan aktif dalam pembentukan MUI. Selain itu, anggaran pembiayaan MUI senantiasa bertumpu pada subsidi pemerintah. Boleh jadi itulah yang membuat problem bagi independensi MUI pada masa Orde Baru, dan beberapa hal juga hingga kini, banyak melayani kepentingan

${ }^{8}$ Fawaizul Umam, Kala Beragama Tak Lagi Merdeka: Majelis Ulama dalam Praksis Kebebasan Beragama (Jakarta: PrenadaMedia Group, 2015), 143.

${ }^{9}$ https://mui.or.id/sejarah-mui/ (diakses pada 20 April, 15.20 WIB).

${ }^{10}$ Ibid.

${ }^{11}$ Umam, Kala Beragama, 146-147. 
pemerintah dari pada kepentingan masyarakat. ${ }^{12}$ Melihat proses institusionalisme peran profetik ulama dalam bentuk MUI tersebut, sulit untuk tidak menyebut steril dari kepentingan politik.

Dalam sepak terjangnya mengawal keagamaan Muslim Indonesia, peran MUI yang paling terlihat kasat mata adalah respon terhadap dinamika praksis kebebasan beragama, khususnya terkait munculnya aliran keislaman yang berbeda. Dalam hal itu, MUI berupaya memperkuat dirinya sebagai otoritas pengontrol akidah dengan cara menetapkan 10 kriteria sesat sebagai pedoman untuk mendeteksi legitimate atau tidaknya suatu aliran. ${ }^{13}$ Dengannya, seolah masyarakat dan MUI daerah mempunyai pedoman untuk secara sederhana menilai menyimpang tidaknya suatu kelompok keagamaan. Dengan fatwa itu juga, masyarakat seperti memiliki legitimasi untuk melakukan mịnah teologis terhadap sekte yang disinyalir keluar dari paham mainstream.

Fatwa "sesat dan menyesatkan" tersebut memainkan peran efektif terutama pasca lengsernya Soeharto sebagai "pelestari ortodoksi". Terutama setelah pengharaman paham pluralisme, liberalisme dan sekularisme. Di titik ini, MUI semakin menjadi ancaman bagi cita-cita pemenuhan hak kebebasan beragama dan ide pluralisme agama. ${ }^{14}$ Fatwa tersebut sukses sebagai instrumen diskursif, terlebih setelah wacana tersebut dipanggungkan di ruang publik dan berlangsung melalui praktik diskursif.

Dalam kerangka definitif Michael Foucault, term diskursus atau wacana berarti pemahaman, pengetahuan, dan sistem abstrak pemikiran. ${ }^{15}$ Diskursus juga bermakna cara menghasillkan pengetahuan, beserta praktik sosial yang menyertainya; relasi kekuasaan yang ada di balik pengetahuan dan praktik sosial tersebut. ${ }^{16}$ Kuasa diskursuslah yang kemudian membangun pengetahuan atau konsep kebudayaan tertentu. Dengan kata lain, istilah diskursus Foucault dapat dipakai untuk menggambarkan fatwa sesat MUI

\footnotetext{
12 Ibid., 150.

13 Adapun kriteria sesat versi Mui adalah sebagaimana telah disebut di atas. Lihat juga Lihat Al Makin, Nabi-nabi Nusantara, 190.

14 Umam, Kala Beragama, 174.

15 Alexander Aur, Pascastrukturalisme Michael Foucault dan Gerbang Menuju Dialog antar Peradaban, dalam Teori-teori Kebudayaan, ed. Mudji Sutrisno, dkk. (Yogyakarta: Kansius, 2005), 147.

16 Paul Rabinow (ed.), Pengetabuan dan Metode: Karya-karya Penting Foucault, terj. Arief (Yogyakarta: IKAPI, 2009), 9.
} 
sebagai instrumen untuk mendikte dan menguasai pengetahuan publik tentang apa yang disebut keberagamaan, penodaan agama, penafsiran, dan sebagainya.

Penguasaan itu dimungkinkan karena, mengikuti perspektif Foucault, taktik pengendalian wacana, salah satunya melalui fatwa, tidak terlepas dari relasi kuasa yang selalu berkelindan dengan pengetahuan. Logikanya, kekuasaan mampu memproduksi pengetahuan tertentu dan disebar lewat wacana yang dibentuk oleh keuasaan itu sendiri. Karenanya, kekuasaan selalu berpretensi untuk melahirkan "rezim kebenaran" sesuai kehendaknya.

Dalam konteks MUI, kekuasaan dan wacana itu muncul dari posisi institusionalnya sebagai kumpulan ulama "resmi" dan "semi negara" sekaligus dari kapasitas intelektual-teologis para elitnya. Dengan kekuasaan dan pengetahuan itu, mudah bagi MUI mengontrol wacana keberagamaan masyarakat yang secara kultural mempercayai keulamaan anggotanya. Melalui fatwa dan otoritas teologis yang mereka klaim, MUI sukses memunculkan diskursus baru, yakni wacana keagamaan versi "arus utama". ${ }^{17}$

\section{Re-Produksi Makna Dalāl dalam Alquran: Pendekatan Semantik}

Secara prinsip, semantik adalah kajian analitis terhadap istilah kunci bahasa yang akarnya sampai pada pemahaman konseptual weltanschauung (pandangan dunia) masyarakat pengguna bahasa tersebut. ${ }^{18}$ Dalam hal ini, yang menjadi fokus analisis adalah term dalla (fil mà dị, sesat) dalam Alquran.

Makna dasar dalla (nominal: dalā) adalah menyimpang dari jalan yang lurus, ${ }^{19}$ antonim dari kata al-rashäd, al-buda. ${ }^{-20}$ Menurut Toshihiko Izutsu, kata ini dapat digunakan dalam berbagai tingkat pembicaraan (religious dan non-religius). Dalam pengertian yang non-religius, misalnya: kehilangan jalan pada saat berpergian di padang pasir. ${ }^{21}$ Begitu pula menurut Bint al-Shātị, kata d̦alla pada mulanya hanya

17 Umam, Kala Beragama, 176.

18 Toshihiko Izutsu, Relasi Tuban dan Manusia: Pendekatan Semantik Terbadap AlQur'an, terj. Agus Fahri Husein, dkk. (Yogyakarta: Tiara Wacana, 1997), 3.

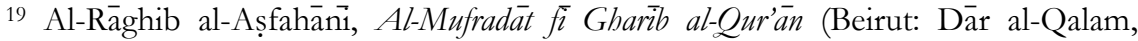
1992), 509.

${ }^{20}$ Muhammad b. Manzūur, Lisān al-'Arab, Vol. 5 (Mesir: Dār al-Hadith, 2003), 520.

21 Toshihiko Izutsu, Konsep-konsep Etika Religius Dalam Qur'an, terj. Agus Fahri Husein, dkk. (Yogyakarta: Tiara Wacana, 2003), 160. 
digunakan untuk arti tersesat ketika berada di jalan. ${ }^{22}$ Kata ini juga digunakan untuk mengungkapkan ketidaktahuan seseorang terhadap tempat tertentu dan guna menunjuk pada sesuatu yang menghalangi jalan. ${ }^{23}$

Dari beberapa contoh di atas, dapat disimpulkan bahwa, pada masa pra Alquran, daläl memiliki arti material. Dalam Alquran pun terdapat penggunaan non-religius terhadap kata ini, di antaranya terdapat dalam surah Yüuf [12]: 8, yang bercerita mengenai kecintaan Nabi Ya'qūb kepada putranya-Nabi Yūsuf. Di surah yang sama, tepatnya ayat 30, kata dalāl juga dipakai dalam arti non-religius:

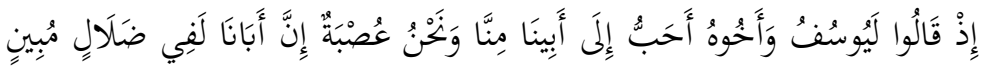

$$
\begin{aligned}
& \text { (يوسف:8) }
\end{aligned}
$$

ketika mereka berkata, sesungguhnya Yusuf dan saudaranya, lebih dicintai ayah dari pada kita, padahal kita adalah satu golongan (yang kuat). Sungguh, ayah kita dalam kekeliruan yang nyata. ${ }^{24}$

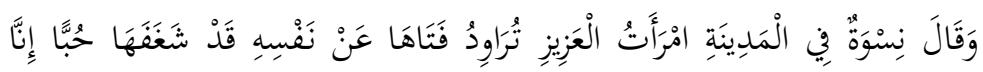

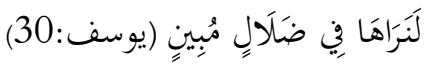

Dan perempuan-perempuan di kota berkata, istri al-'Aziz menggoda dan merayu pelayannya untuk menundukkan dirinya, pelayannya benar-benar membuatnya mabuk cinta. Kami pasti memandang dia dalam kesesatan yang nyata.

Dua ayat di atas menggambarkan dalăl mengandung pengertian bahwa perbuatan tersebut merupakan sesuatu yang bertentangan dengan pengertian moral yang umum. Tetapi tentu saja makna dasar tersesat dari jalan yang benar tetap melekat. Bahkan, terdapat term dalāl dalam Alquran yang diatributkan kepada Nabi Muhammad, dengan bermakna bingung (QS. al-Ḍuhā [93]: 7),

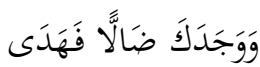

\footnotetext{
22 'Āishah Muhammad 'Āì 'Abd al-Rahmān b. al-Shāti', Al-Tafsìr al-Bayāñ̄ li alQur'an al-Karim (Mesir: Dār al-Ma'rifah, tt), 44. Lihat Juga al-Ṭāhir b. 'Äshür, AlTabrir wa al-Tanwìr, Vol. 8 (Tunisia: Dār al-Tünisiyah,1984), 191.

${ }^{23}$ Al-Shāti', Al-Tafsìr al-Bayāni, 44.

24 Departemen Agama RI, Al-Hikmah: Al-Quran dan Terjemahnya (Bandung: Dipenogoro, 2008) 236.
} 
Dan Dia mendapatimu (Muhammad), dalam keadaan yang bingung, lalu Dia memberikan petunjuk. ${ }^{25}$

Alquran juga merekam kata daläl yang digunakan oleh Nabi Musa sebagai pengakuan dirinya telah melakukan kesalahan. ${ }^{26}$ Dengan demikian, kata daläl yang dinisbahkan kepada dua Nabi tersebut adalah bermakna kesalahan manusiawi yang memiliki keterbatasan tertentu.

Selain makna dasar non-religius, dalāl juga dapat bermakna sesat dengan nuansa religius. Transisi makna tersebut terjadi ketika term ini terhubung dengan term lain, yang bisa disebut dengan makna relasional, yakni makna konotatif yang diberikan dan ditambahkan pada makna yang sudah ada dengan meletakkan kata itu pada posisi khusus dalam bidang khusus. ${ }^{27}$ Dengan kata lain, makna baru pada sebuah kata bergantung pada kalimat di mana kata itu berada.

Kata dalàl memiliki makna relasional ketika term ini terkait langsung dengan term-term tertentu, antara lain: sirat al-mustaqim dan Allah. Term Allah merupakan kata fokus tertinggi dalam Alquran, yang menurut Izutsu, tidak ada yang melebihi nilai sekaligus kedudukannya. Hal itu karena weltanschaunng Alquran bersifat teosentrik, dan dalam sistem tersebut, konsep Allah menguasai keseluruhannya. ${ }^{28}$ Demikian pula ketika membahas konsep dalăl, tidak dapat dipisah dari relasinya dengan term Allah. Dengan hubungan relasional tersebut, sebagaimana akan terlihat, makna dalä sudah bergeser ke sisi religius, karena relasi term Allab-dalä adalah relasi mengenai bimbingan Allah. Karenanya, di banyak kesempatan dalam Alquran, dalāl banyak disebut beriringan dengan term buda:

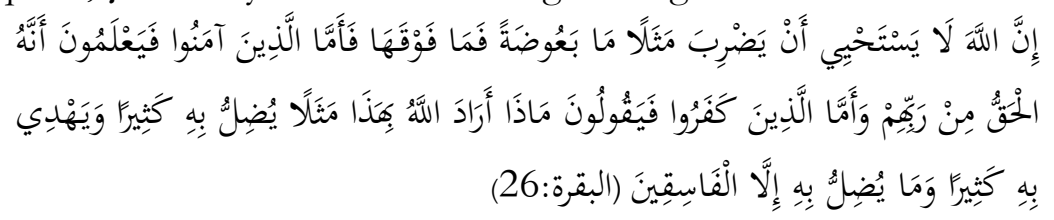

Sesungguhnya Allah tidak segan membuat perumpamaan seekor nyamuk atau yang lebih kecil dari itu. Adapun orang beriman mereka tahu itu kebenaran dari Tuhan. Tapi mereka yang kafir berkata, "apa maksud Allah dengan perumpamaan ini?" dengan

25 Ibid., 596.

${ }^{26}$ Lihat QS. al-Shu'arā' [26]: 20.

${ }^{27}$ Izutsu, Relasi Tuban, 12.

${ }^{28}$ Ibid., 101. 
itu, banyak orang yang dibiarkannya sesat, dan dengan itu banyak pula yang diberi petunjuk. Dan tidak ada yang disesatkan kecuali orang fasik. ${ }^{29}$

Sedangkan relasi daläl dengan sirạt al-mustaqim erat kaitannya dengan konsepsi Alquran mengenai jalan. Jalan yang dimaksud di sini bukan sekedar jalan, unsur yang paling menentukan mengenai jalan ini menurut cara pandang Alquran adalah kelurusannya. ${ }^{30}$ Dengan kata lain, menurut konteks Alquran, bila manusia mengikuti jalan itu, maka dia menuju pada keselamatan. Lurusnya jalan Tuhan bertentangan dengan "bengkoknya" jalan yang lain, jalan yang tidak menuntun manusia pada tujuannya, tapi membelokkannya:

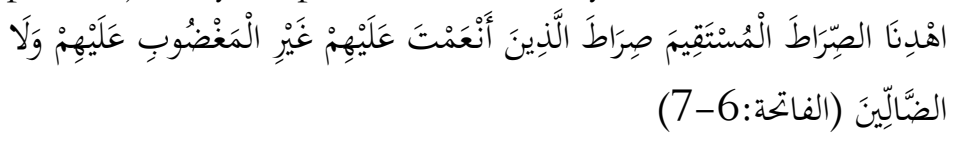

Tunjukkanlah kami jalan yang lurus (6) jalan orang-orang yang telah engau beri nikmat kepadanya, bukan jalan mereka yang dimurkai, dan bukan (pula jalan) mereka yang sesat. ${ }^{31}$

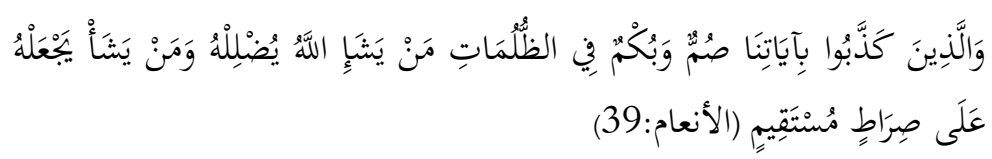

Dan orang yang mendustakan ayat kami adalah tuli, bisu dan berada dalam gelap gulita. Barangsiapa dikehendaki Allah (dalam kesesatan), niscaya disesatkan-Nya. Dan barangsiapa dikehendaki Allah (untuk diberi petunjuk), niscaya Dia menjadikannya berada di atas jalan yang lurus. ${ }^{32}$

Dari beberapa ayat di atas, dapat dilihat keterkaitan antar dalāl dan sirạt al-mustaqim. Makna dasar pada term daläl bukan lagi tersesat dari jalan yang konkret, melainkan bertransformasi menjadi jalan dengan nuansa religius.

Analisis semantik berikutnya adalah mengenai struktur batin (deep stucture), yakni mengungkap fakta pada dataran yang lebih riil, sehingga

\footnotetext{
${ }^{29}$ Ibid., 5.

${ }^{30}$ Izutsu, Relasi Tuhan, 157.

${ }^{31}$ Ibid., 1.

32 Ibid., 132.
} 
fakta tersebut tidak menimbulkan kekaburan pada dataran manapun. ${ }^{33}$ kata daläl dengan analisis struktur batin hendak membedah bagaimana term tersebut terstruktur secara semantik. Struktur batin dalal terkait dengan beberapa term berikut: qäsiyah al-qulb, ${ }^{34}$ shirk, ${ }^{35}$ kufr, ${ }^{36}$ dan ittiba ${ }^{6}$ al-bawa. ${ }^{-37}$

Terkait dengan qasiyah al-qulb dalam surah al-Baqarah, kerasnya hati dimetaforkan dengan kerasnya batu, bahkan lebih keras lagi. ${ }^{38}$ Dengan demikian, orang yang hatinya keras sukar menerima kebenaran dari Allah. Dalam surah al-Hadid [57]: 16, kerasnya hati diasosiasikan pada orang abl al-kitāb yang enggan menerima kebenaran. Term shirk, seperti yang terdapat dalam surah al-Nisā' [4]: 116 berkaitan dengan term daläl. Orang yang menyekutukan Allah disebut telah tersesat jauh dan tidak dapat diampuni.

Setelah melewati langkah deep structure, langkah berikutnya adalah penelusuran terhadap bidang semantik, hal ini bertujuan memahami jaringan konseptual yang terbentuk oleh kata dalal. Karena dalam Alquran ada beberapa term yang memiliki sinonimitas makna dengan dalal. Pengetahuan mengenai bidang semantik ini tentu merupakan pengantar kepada pemahaman yang utuh terhadap term daläl. Adapun beberapa term tersebut adalah: ghawā, zaghä, 'amiha, ghaflah, qasata, nakaba, taha.

Ghawa adalah salah satu kata yang juga memiliki arti "tersesat dari jalan yang benar". ${ }^{39}$ Dalam ayat berikut, ghawā bertentangan dengan muttaqi yang berarti "takut kepada Tuhan":

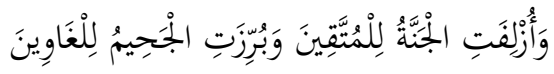

Dan surga didekatkan kepada orang-orang yang bertaqwa (90) dan neraka Jahim diperlihatkan kepada orang-orang sesat (91)."

Selain ghaw $\bar{a}$, raghà juga memiliki makna melenceng atau menyimpang dari jalan yang benar. ${ }^{40}$ Namun, penggunaan ragha dalam

\footnotetext{
2002, 30.

${ }^{34}$ QS. Al-Zumar [39]: 22.

${ }^{35}$ QS. al-Nisā' [4]:116.

${ }^{36}$ QS. al-Nisā' [4]: 136.

${ }^{37}$ QS. al-Mä'idah [5]: 48.

${ }^{38}$ Lihat QS al-Baqarah [2]: 74.

${ }^{39}$ Izutsu, Konsep-konsep, 164.
}

${ }^{33}$ Chafid Wahyudi, "Pandangan Dunia Al-Qur'an Tentang Taubah (Aplikasi Pendekatan Semantik Terhadap Al-Qur'an)," Skripsi, IAIN Sunan Ampel Surabaya, 
Alquran identik dengan berpalingnya hati. Jika hati seseorang berpaling dari kebenaran, kebanyakan Alquran menggunakan kata raghä:

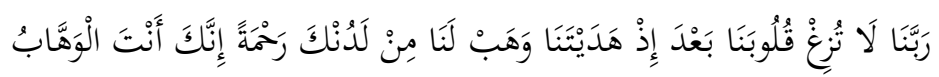

"Ya Tuhan kami, janganlah engkau condongkan hati kami, pada kesesatan setelah Engkau berikan petunjuk pada kami, dan karuniakanlah kepada kami rahmat dari sisi-Mu, sesungguhnya Engkau Maha Pemberi.” (QS. A $<$ li ‘Imra $>$ n [3]: 8) ${ }^{41}$

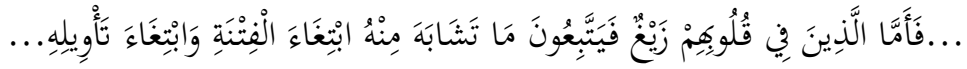

$$
\begin{aligned}
& \text { “...Adapun orang-orang yang hatinya condong pada kesesatan }
\end{aligned}
$$

Term selanjutnya adalah 'amiha bermakna bergelimang dalam kesesatan, benar-benar bingung jalan mana yang harus ditempuh. Kata kerja ini cocok untuk menggambarkan orang kafir yang mondarmandir di dunia ini, tanpa pernah menemukan arah yang benar. ${ }^{43}$ Dalam Alquran 'amiha disebutkan sebanyak tujuh kali dengan menggunakan derivasi mudäri, ${ }^{44}$ yang semuanya menggambarkan bergelimang dalam kesesatan, sebagaimana ayat berikut:

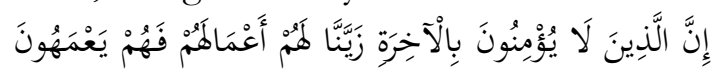

"Sesungguhnya orang-orang yang tidak beriman kepada akhirat, Kami jadikan terasa indah bagi mereka perbuatan-perbuatan mereka, sehingga mereka bergelimang dalam kesesatan." (QS. Alnaml [93]: 4$)^{45}$

Ghaflah termasuk kata yang serupa dengan dalla, secara harfiah berarti lalai atau lengah. ${ }^{46}$ Dalam arti non-religius ini, Alquran menggunakannya secara maksimal, hingga menurut Izutsu, tidak ada kata yang dapat menunjukkan dengan lebih baik mengenai makna

\footnotetext{
40 Ibid., 165.

${ }^{41}$ Depag RI, Al-Hikmah: Al-Quran, 50.

42 Ibid., 50.

${ }^{43}$ Izutsu, Konsep-konsep, 165.

${ }_{44}$ Muḥammad Fu'ād 'Abd al-Baqi', Al-Mu'jam al-Mufahras li Alfäz al-Qur'ān al-Karim (Beirut: Dār al-Ma'rifah, 2002), 488.

${ }^{45}$ Depag RI, Al-Hikmah: Al-Quran, 377.

${ }^{46}$ Izutsu, Konsep-konsep, 166.
} 
dasar tersebut. ${ }^{47}$ Alquran memberikan contoh yang akurat berkaitan dengan bab kisah Nabi Yüsuf yang dibawa keluar oleh saudarasaudaranya hingga membuat Nabi Ya'qüb cemas:

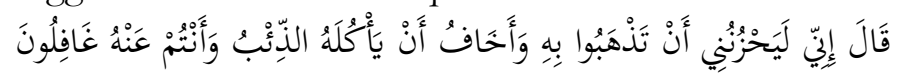

"Ya'qub berkata, sesungguhnnya kepergian kamu bersama dia (Yusuf) sangat menyedihkanku dan aku khawatir dia dimakan serigala, sedang kamu lengah darinya." (QS. Yu>suf [12]: 13)

Term dalāl pernah dipakai Alquran guna mendeskripsikan kesesatan orang kafir yang lebih parah ketimbang binatang ternak, ${ }^{48}$ term ghaflah pun ternyata pernah digunakan dalam konteks yang sama:

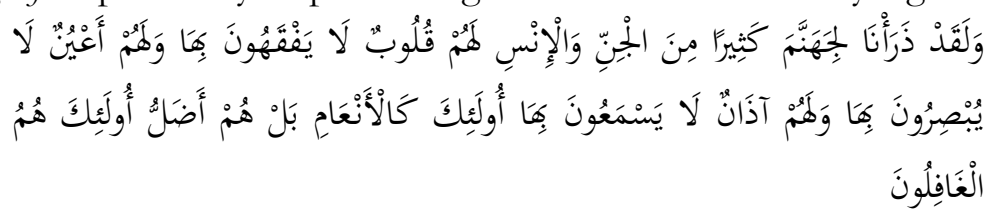

"Dan sungguh, akan kami jadikan neraka jahannam banyak dari kalangan jin dan manusia. mereka memiliki hati, tapi tidak digunakan untuk memahami, mereka punya mata, tapi tidak digunakan untuk melihat (ayat Alah), mereka punya telinga, tapi tidak dipergunakan untuk mendengar (ayat Allah). mereka seperti hewan ternak, bahkan lebih sesat. Mereka itulah orang-orang yang lengah.” (QS. al-A'raf [7]: 179) ${ }^{49}$

\section{Reproduksi Makna Dalāl dalam Konteks Negara Bangsa}

Annemarie Schimmel dalam ceramahnya di Universitas Harvard pada tahun 2002 mengatakan, Islam biasanya diperlakukan dengan buruk dan sembrono. Karena sebagian besar sejarawan agama dan mayoritas orang pada umumnya lebih melihatnya sebagai agama primitif yang erat membahas hukum. Namun, mengutip Gerad van Der Leeuw, Schimmel menunjukkkan bahwa sesungguhnya Islam adalah agama yang berorientasikan cinta-kasih. ${ }^{50}$

Secara teoritis gagasan islam cinta-kasih bukanlah gagasan semu belaka, melihat banyaknya gagasan Alquran yang melandasinya, antara lain; seperti bagaimana Alquran menekankan prinsip persaudaraan; ${ }^{51}$

\footnotetext{
${ }^{47}$ Ibid., 166.

${ }^{48}$ Lihat QS. al-Furqān [25]: 44.

${ }^{49}$ Depag RI, Al-Hikmah: Al-Quran, 174.

${ }^{50}$ Bagir, Islam Tuhan, 231.

${ }^{51}$ QS. al-Hujurāt [49]: 10.
} 
menjadi pemaaf dan mengajak pada jalan kebaikan; ${ }^{52}$ bersikap adil dan berdiskusi dengan cara yang paling baik meski mereka tetap menyatakan permusuhan, ${ }^{53}$ mengajak kebaikan dengan cara yang damai ${ }^{54}$ tidak memaki apa yang mereka sembah (selain Allah), sebagai bentuk saling menghargai agar tidak memicu saling memaki, ${ }^{55}$ dan menjadi rahmat bagi alam semesta. ${ }^{56}$

Melihat kerap terjadinya kekerasan atas nama agama (baca: Islam), terlihat bahwa ada kesenjangan antara ajaran teoritis Alquran dengan cara Muslim mengimplementasikan ajaran substansial Alquran yang bernuansa rahmat bagi seluruh alam. Kegagalan tersebut menjadi penghalang bagi hadirnya prinsip kedamaian Islam. Dalam hal ini, relevanlah apa yang dikemukakan Muhammad 'Abduh, bahwa ajaran Islam tertutup oleh perilaku umat Muslim.

Di kalangan masyarakat Indonesia, sikap menerima perbedaan sebagai keniscayaan belum sepenuhnya diterima. Dimensi kelianan kerap dibenturkan dengan ortodoksi Islam yang banyak diyakini sebagai bentuk final dari ekspresi beragama. Terlebih menerima plualisme sebagai ideologi, hal itu dirasa ganjil karena dianggap tidak berakar dalam tradisi Islam. Padahal, dalam kerangka normatif, pluralitas keberagamaan adalah, meminjam istilah Masdar Hilmy, bard fact (kenyataan keras). ${ }^{57}$ Begitu banyak ayat Alquran yang mengemukakan tentang ide pluralisme. Allah yang menghendaki makhluknya berbeda tidak hanya dalam realitas fisikal, melainkan juga berbeda-beda dalam ide, gagasan, berkeyakinan, dan beragama. Dalam beberapa ayat ditegaskan bahwa jika Allah berkenan, maka manusia diciptakan dalam satu golongan saja. ${ }^{58}$

Ketunggalan dalam beragama adalah hal yang tidak dikehendaki Allah. Dalam ayat yang lain disebutkan tidak ada paksaan dalam memasuki agama. Berdasarkan ayat tersebut dapat dipahami bahwa di samping tidak boleh ada paksaan bagi seseorang dalam memeluk

\footnotetext{
52 QS. al-A'rāf [7]: 199.

${ }^{53}$ QS. al-'Ankabūt [29]: 46.

${ }^{54}$ QS. al-Nahl [16]: 125.

55 QS. al-An`ám [6]: 108. Lihat juga Said Aqiel Siradj, "Tasawuf Sebagai Basis Tasāmuḥ: dari Social Capital Menuju Masyarakat Moderat", dalam Al-Tahrir, Vol. 13, No. 1, (Mei 2013), 91.

${ }^{56}$ QS. al-Anbiyà' [21]: 107.

57 Masdar Hilmy, Islam Profetik: Substansi Nilai-nilai Agama dalam Ruang Publik (Yogyakarta: Kansius, 2008), 207.

${ }^{58}$ Lihat QS. Hūd [11]: 118, al-Mà'idah [5]: 58.
} 
agama, seseorang juga dibebaskan apabila memilih untuk tidak beragama. Karena jalan yang benar dan jalan yang salah telah dibentangkan. ${ }^{59}$ Bahkan, perilaku sosial Nabi Muhammad secara eksplisit menunjukkan penerimaan terhadap yang "lian". Sebagaimana ditegaskan Robert N. Bellah, Nabi Muhammad berhasil menunjukkan kecemerlangan cara memimpin, yang selangkah lebih maju pada zamannya. Di bawah kepemiminannya, suku dan agama di tanah Arab berhasil disatukan dan hidup berdampingan dengan damai. ${ }^{60}$

Berpijak pada ide pluralisme dalam Alquran dan cara beragama Nabi Muhamad, maka tidak hanya secara hukum positif, secara teologis pun adalah bertentangan jika umat Islam mendiskriminasi penganut aliran kepercayaan atau keyakinan lain. Karena misi utama agama adalah upaya membebaskan manusia dari berbagai bentuk penistaan dan kekerasan, baik secara fisik maupun psikis. Dalam hal ini, fatwa MUI tidak hanya menjadi penggerak masa melakukan anarkisme fisik pada terduga aliran sesat. Lebih dari itu, fatwa MUI jelas menjadi kekerasan psikologis.

Berbicara tentang kekerasan non-fisik, Erich Fromm (1900-1980) mengemukakan hal tersebut dengan istilah "sadisme mental". ${ }^{61}$ Sadisme ia definisikan sebagai keinginan kuat untuk mendapatkan kekuasaan atas makhluk lain, yang bisa dengan berbagai wujud. ${ }^{62}$ Dalam hal ini sadisme mental adalah kekerasan yang ditujukan untuk menyakiti mental korban, yang tentu saja dapat melecehkan dan melukai perasaan orang lain bahkan dengan efek yang lebih buruk dari kekerasan fisik. ${ }^{63}$ Kata-kata menjadi pilihan tepat untuk melakukan sadisme mental ini.

Sedangkan dalam kerangka teoritik Johan Galtung, kekerasan terbagi dua: kekerasan personal dan kekerasan struktural. Yang pertama, menurut Galtung adalah kekerasan yang menyasar langsung sisi anatomi manusia, seperti membunuh, melukai, meracuni dan sejenisnya. Sedangkan yang kedua, kekerasan yang objeknya adalah

\footnotetext{
59 Husein Muhammad, "Pluralisme Sebagai Keniscayaan Teologis", dalam Abd. Moqsith Ghazali, Argumen Plualisme Agama (Depok: KataKita, 2009), xvi.

${ }^{60}$ Robert N. Bellah, Beyond Belief: Esai-esai Tentang Agama di Dunia Modern, Terj. Rudy Harisyah Alam (Jakarta: Paramadina, 2001), 210.

${ }^{61}$ Erich Fromm, Akar Kekerasan: Analisis Sosio Psikologis atas Watak Manusia, Terj. Imam Muttaqin (Yogyakarta: Pustaka Pelajar, 2001), 410.

62 Ibid., 456.

${ }^{63}$ Ibid., 410.
} 
bagian psikologi manusia, seperti membatasi gerak manusia lain, membatasi ruang, dan pengendalian otak. ${ }^{64}$

Ditilik dari kerangka kekerasan dua tokoh di atas, sembari melihat laporan The Wahid Institute dan Setara Institute, terlihat bahwa Fatwa MUI secara eksplisit menunjukkan sisi kekerasan psikologis. Menuduh suatu aliran tertentu dengan sesat tentu melukai perasan tertuduh, karena bagaimanapun, bagi pihak yang tertuduh ajarannya mengandung kebenaran tersendiri. Terlebih dalam konteks Indonesia, yang notebene bukan negara agama, tuduhan semacam itu tidak layak diungkapkan.

Pancasila sebagai dasar negara menjadi indikator penting bahwa Indonesia bukanlah negara agama. Pada titik ini, agama-agama yang berada di Indonesia berfungsi memberikan spiritnya secara substantif. Sebab jika terdapat agama tertentu yang berperan dominan, akan berujung pada hal yang dikhawatirkan Bung Karno: diktatorisme mayoritas yang menyulut tirani terhadap minoritas. ${ }^{65}$

Bangunan Indonesia sebagai negara-bangsa di satu sisi, dan pemaknaan dalal yang tidak seluruhnya berbicara sesat dalam arti religius di sisi yang lain, menjadi dasar teoritis bahwa menghakimi orang lain dengan sesat adalah hal yang tidak tepat diterapkan di Indonesia. Untuk itu, perlu adanya rumusan alternatif sebagai perekat sosial antar agama di Indonesia. Dalam hal ini, social capital yang dirumuskan Francis Fukuyama dapat menjadi salah satu solusi.

Pierre Bourdie memberikan pengertian modal sosial dengan seluruh sumber daya, baik aktual mapun potensial, yang mampu menimbulkan hubungan timbal balik antar institusi. ${ }^{66}$ Menurut Fukuyama, modal sosial adalah kumpulan nilai atau norma informal pemberi teladan yang menjadi acuan di antara berbagai anggota sebuah kelompok, yang dengan nilai itu, memungkinkan mereka bekerja sama. ${ }^{67}$

Menilik beberapa definisi modal sosial, Chafid Wahyudi menarik kesimpulan modal sosial adalah "menempatkan kelompok-kelompok yang berada di dalam sebuah jaringan kerja kepercayaan di masyarakat

${ }^{64}$ I. Wasana Windhu, Kekuasaan dan Kekerasan Menurut Johan Galtung (Yogyakarta: Kansius, 1992), 74.

${ }^{65}$ Hilmy, Islam Profetik, 166.

${ }^{66}$ Ghazali Syammi, "Profil Social Capital Suatu Kajian Literatur", dalam Jurnal Bisnis dan Ekonomi, Vol. 17, No. 2 (September, 2010), 174.

${ }^{67}$ Francis Fukuyama, The Great Dismption: Hakikat Manusia dan Rekonstruksi Tatanan Sosial, Terj. Ruslani (Jakarta: Penerbit Qalam, 2000), 22. 
yang rumit bersatu untuk mempertahankan kepentingan mereka melalui norma-norma informal." ${ }^{68}$ Dengan begitu, kata kunci yang bisa menjadi acuan dalam modal sosial adalah kepercayaan, kepentingan, dan persatuan.

Menurut Fukuyama, setiap masyarakat memiliki sosial kapital, yang mungkin menjadi perbedaan antar kelompok masyarakat adalah "radius kepercayaan" itu sendiri. Fukuyama berpandangan bahwa manusia secara hakikat adalah makhluk sosial yang memiliki kemampuan bawaan untuk mencari solusi atas masalah yang timbul dan menciptakan aturan moral guna mengendalikan pilihan individu. Manusia mampu menciptakan ketertiban dengan sendirinya begitu ia memenuhi kebutuhan sehari-hari dan bersinggungan dengan orang lain. ${ }^{69}$

Adalah sangat mungkin menciptakan kelompok yang harmonis tanpa adanya modal sosial, dengan menggunakan mekanisme formal, seperti kontrak, konstitusi, sistem hukum, bahkan yang menyangkut teologi. Namun, norma informal sangat memiliki pengaruh dalam membangun keharmonisan. Kelompok teologis di Indonesia umumnya telah memiliki mekanisme bagaimana berhubungan dengan sesama manusia. Namun, kenyataannya, sebagaimana telah dipaparkan, kelompok agama mayoritas gagal menempatkan kekuatannya untuk hidup damai dengan agama minoritas.

Karenanya, Fukuyama berkeyakinan bahwa modal sosial memungkinkan kelompok-kelompok yang berbeda dalam masyarakat yang kompleks untuk mengikat bersama demi membela kepentingan mereka, yang mungkin diabaikan oleh negara. ${ }^{70} \mathrm{Hal}$ itu mungkin tercapai syarat modal sosial terpenuhi. Suryadi dan Haris El Mahdi menampilkan tiga pilar modal sosial ala Fukuyama: kepercayaan, hubungan timbal balik, dan aksi bersama. ${ }^{71}$

Kepercayaan bagi Fukuyama menjadi pondasi utama yang menjadi basis bagi terjalinnya kerja sama maupun koordinasi. Kepercayaan yang terbangun kokoh meniscayakan adanya relasi timbal balik dan aksi bersama yang orisinal, dan pada puncaknya

${ }^{68}$ Chafid Wahyudi, Nabdlatul Ulama \& Civil Religion: Melacak Akar Civil Religion dalam Keagamaan NU (Yogyakarta: Graha Ilmu, 2013), 17.

${ }^{69}$ Ibid.

${ }^{70}$ Fukuyama, The Great Disruption, 25.

71 Suryadi dan Haris El Mahdi, "Menemukan Kembali Kapital Sosial Bangsa Indonesia”, dalam Interaktif, Vol. 01, No. 01 (2010), 27. 
mampu menjadi motor penggerak seluruh potensi modal sosial yang tersembunyi. $^{72}$

Kepercayaan bisa dihadirkan dengan menguatkan tatanan moral yang telah menjadi sifat bawaan manusia, dengan menempatkan norma atau aturan sebagai integrasi-efektif ditengah keragaman dan kolektifitas. Narasi yang harus diwajahkan untuk menjadikan moral sebagai awal pijakan kepercayaan adalah semangat keberagaman, tolong-menolong, dan saling menghargai hak satu sama lain. Memahami bahwa tiap inidividu memiliki hak adalah penting, dalam konteks keragaman agama di Indonesia yang telah dilegalkan, individu harus membangun hak tersebut terejawantahkan dengan baik sebagaimana mestinya: tidak mengusik keberagamaan orang lain. jika hal tersebut menjadi pemahaman kolektif kelompok agama mayoritas, minoritas tidak akan memandang mayoritas sebagai monster diktator yang siap menyingkirkan kapan pun. Alih-alih, minoritas akan menaruh kepercayaan besar.

Kepercayaan itu yang kemudian membawa modal sosial kedua akan terbangun, yakni timbal balik. Adalah sebuah keniscayaan kelompok agama akan saling menghargai jika kepercayaan "hak beragama" dibangun dengan maksimal. Pada puncaknya, aksi bersama dalam menjaga "keragaman ruang publik" akan mencapai titik puncak.

\section{Kesimpulan}

Keragaman Indonesia yang terdiri dari berbagai suku, budaya dan agama direkatkan dengan UUD 1945. Artinya, setiap langkah hidup bersama harus mengacu pada payung besar tersebut. Salah satu jaminan yang tertera adalah kebebasan bagi tiap individu untuk memeluk agama sesuai dengan kecondongan dirinya. Bahkan negara menjamin keamanan dalam menjalankan ibadah.

Namun yang terjadi adalah sebaliknya, keragaman agama di ruang publik telah menimbulkan perpecahan cukup signifikan dibanding dengan konflik lain. hal ini karena warga Indonesia memiliki religiusitas yang tinggi, hingga tindak-tanduk perihal agama bisa menjadi hal yang sensitif. Aliran-kepercayaan minoritas kerap mendapat diskriminasi publik. Klaim sesat menjadi grand framing kelompok mayoritas.

${ }^{72}$ Ibid., 27. 
Alquran sendiri menyampaikan term sesat dalam konteks yang tidak monolitik. Sebagaimana pendekatan semantik di atas. Karenanya, pandangan Alquran yang demikian hendaknya dipahami dan diterapkan dalam konteks negara-bangsa, dalam hal ini, Indonesia. Pungkasnya, pemahaman itu dapat menjadi pijakan awal untuk membangun modal sosial yang kokoh.

\section{Daftar Pustaka}

Al Makin. Nabi-nabi Nusantara. Yogyakarta: Suka Press, 2017.

Aṣfahāni (al), al-Rāghib. Al-Mufradāt fī Gharìb al-Qur'ān. Beirut: Dār alQalam, 1992.

Aur, Alexander. Pascastrukturalisme Michael Foucault dan Gerbang Menuju Dialog antar Peradaban, dalam Teori-teori Kebudayaan. Diedit oleh Mudji Sutrisno, dkk. Yogyakarta: Kansius, 2005.

Bāqi' (al), Muhammad Fu'àd 'Abd. Al-Mu'jam al-Mufahras li Alfä̌̀ alQur'an al-Karim. Beirut: Dār al-Ma'rifah, 2002.

Bagir, Haidar. Islam Tuban Islam Manusia: Agama dan Spiritualisme di Zaman Kacau. Bandung: Mizan, 2014.

Bellah, Robert N. Beyond Belief: Esai-esai Tentang Agama di Dunia Modern. Diterjemahkan oleh Rudy Harisyah Alam. Jakarta: Paramadina. 2001.

Fromm, Erich. Akar Kekerasan: Analisis Sosio Psikologis atas Watak Manusia. Diterjemahkan oleh Imam Muttaqin. Yogyakarta: Pustaka Pelajar, 2001.

Fukuyama, Francis. The Great Disruption: Hakikat Manusia dan Rekonstruksi Tatanan Sosial. Diterjemahkan oleh Ruslani (Jakarta: Penerbit Qalam, 2000.

Ghazali, Abd. Moqsith. Argumen Plualisme Agama. Depok: KataKita, 2009.

Hilmy, Masdar. Islam Profetik: Substansi Nilai-nilai Agama dalam Ruang Publik. Yogyakarta: Kansius, 2008.

https://mui.or.id/sejarah-mui/ (diakses pada 20 April, 15.20 WIB).

Manzüur (Ibn), Muhammad. Lisān al-'Arab. Mesir: Dār al-Hadith, 2003. Institute, The Wahid. Laporan Sementara Dinamika Kebebasan Beragama dan Berkeyakinan (KBB) di Indonesia Tabun 2015, 2016.

Izutsu, Toshihiko. Relasi Tuban dan Manusia: Pendekatan Semantik Terhadap Alquran. Diterjemahkan oleh Agus Fahri Husein, dkk. Yogyakarta: Tiara Wacana, 1997. 
Izutsu, Toshihiko. Konsep-konsep Etika Religius Dalam Qur'an. Diterjemahkan oleh Agus Fahri Husein, dkk. Yogyakarta: Tiara Wacana, 2003.

Lawrence, Bruce B. Islam Tidak Tungggal: Melepaskan Islam Dari Kekerasan. Diterjemahkan oleh Harimukti Bagoes Oka. Jakarta: Serambi Ilmu Semesta, 2004.

Madjid, Nurcholis. Cendekiawan dan Religiusitas Masyarakat. Jakarta: Paramadina, 1999.

Nino (ed.), UUD 1945 \& Kabinet Kerja 2014-2019. Jakarta: Salaris

Rabinow, Paul. (ed.), Pengetahuan dan Metode: Karya-karya Penting Foucault. Diterjemahkan oleh Arief. Yogyakarta: IKAPI, 2009.

RI, Departemen Agama. Al-Hikmab: Al-Quran dan Terjemahnya. Bandung: Dipenogoro, 2008.

Setara Institute. Kondisi Kebebasan Bergama/Berkeyakinan dan Minoritas di Indonesia tabun 2018.

Siradj, Said. Aqiel "Tasawuf Sebagai Basis Tasāmuḥ: dari Social Capital Menuju Masyarakat Moderat." Al-Tabrir, Vol. 13, No. 1, (Mei 2013).

Suryadi, dan Haris El Mahdi. "Menemukan Kembali Kapital Sosial Bangsa Indonesia." Interaktif, Vol. 01, No. 01 (2010).

Shāti' (al), 'Āishah 'Abd al-Raḥmān Bint. Al-Tafsìr al-Bayānì li alQur'an al-Karim. Mesir: Dār al-Ma'rifah, t.th.

Syammi, Ghazali. "Profil Social Capital Suatu Kajian Literatur." Jurnal Bisnis dan Ekonomi, Vol. 17, No. 2 (September, 2010)

Umam, Fawaizul. Kala Beragama Tak Lagi Merdeka: Majelis Ulama dalam Praksis Kebebasan Beragama. Jakarta: Prenada Media Group, 2015. Wahyudi, Chafid. Nabdlatul Ulama \& Civil Religion: Melacak Akar Civil Religion dalam Keagamaan NU Yogyakarta: Graha Ilmu, 2013. - "Pandangan Dunia Alquran Tentang Taubah (Aplikasi Pendekatan Semantik Terhadap Alquran)." Skripsi, IAIN Sunan Ampel Surabaya, 2002.

Windhu, I. Wasana. Kekuasaan dan Kekerasan Menurut Johan Galtung. Yogyakarta: Kansius, 1992. 